\title{
The Role of Rural Women in Environmental Management in Myanmar: A Case Study of Ngaputaw Township
}

\author{
Thin Thin Aye $^{1 *}$ \\ ${ }^{1}$ University of Yangon, Myanmar \\ *Corresponding author: Thin Thin Aye: thinthinaye.dr5@gmail.com
}

\section{Abstract:}

Citation: Aye T.T. (2018) The Role of Rural Women in Environmental Management in Myanmar:A Case Study of Ngaputaw

Township.Open Science Journal 3(1)

Received: $24^{\text {th }}$ May 2017

Accepted: $7^{\text {th }}$ June 2017

Published: $1^{\text {st }}$ February 2018

Copyright:@ 2018 This is an open access article under the terms of the Creative Commons Attribution License, which permits unrestricted use, distribution, and reproduction in any medium, provided the original author and source are credited.

Funding: The author(s) received no specific funding for this work

Competing Interests: The author have declared that no competing interests exists.

The purpose of this research is to examine the role of women in environmental management in Myanmar. In Myanmar society, women have a tradition of environmental care. From childhood, young Myanmar girls are trained to undertake work in and around their house. It is a common sight in rural areas to see young girls caring for their siblings and collecting water or firewood during school holidays. Women in rural areas are traditionally aware of how to use fuel wood properly, how to get and store safe drinking water, and which plants can be used as indigenous medicine. In this way women have played an important role in reducing resource use, reusing and recycling resources to minimize waste and excessive consumption. This research revolves around the issues such as women's perspectives on the environment; the nature of their participation to engage in environmental protection and conservation; and environmental management policies of Myanmar.

Keywords: Women, Water, Forest, Firewood, Environmental Policies

\section{Introduction}

Governments the world over are confronted with how to synthesize the global and national dimensions of increasing environment problems, such as the effects of climate change, destruction of biological resources and deforestation, and in some cases the impact of desertification. The need to protect the environment is 
imperative. Natural disastersare becoming more frequent and more intense, and the impact of population growth on scarce resources raise the possibility of environmental degradation. Managing the environment in a more sustainable way is a pressing global challenge. In some countries women are taking on active roles in environmental management.

Among the Millennium Development Goals (MDGs), Goal 7 is to ensure environmental sustainability. As the population grows and the economy progresses, demand for basic needs and consumergoods rises as well. Increase in household incomes giving greater purchasing power, exacerbates this trend. The increase in population places greater demands on natural resources thusaffecting the environment. Women have a significant role to play in, promoting sustainable development as envisaged in the MDGsespecially those related to environmental protection.

When international debates related to women's participation in environmental management are examined, it can be seen that in every aspect emphasis has been on a promoting women's participation. For instance, many program areas of Agenda 21 incorporated the role of women. Principle 20 of the Rio Declaration states that "women have a vital role in environmental management and development. Their full participation is therefore essential to achieving sustainable development." This article will examine these issues as they pertain to Myanmar and its need to develop appropriate policies for the protection of its natural resources.

\section{Women in Agriculture in Myanmar}

In Myanmar, the main economy is agriculture which contributes about 64 per cent to the country's GDP Thus economic growth of the country through agricultural development is essential to maintain food security for the increasing population. There is an assumption that rural women have more contact with the environment than urban women as they are heavily involved in the agricultural activities of their communities. They prepare food, take care of the children, and help to plough fields, harvest crops and tend animals. Men migrate to urban centres to look for work, thus diversifyinginto laboring or small business, while women often must remain at home to fulfil responsibilities such as caring for the family, sick and elderly. They rely on the resources available to them locally to fulfil these needs. The use of natural resources by women and their close dependence on these for their daily lives has resulted in a predominant set of perspectives that highlight women as having a special relationship with the environment, as its users or managers.

Women have numerous recorded successes in solving environmental problems. To better understand how women manage local resources in the rural areas, this research focuseson understanding the linkages between women and environmental managementwhich have become an important focus of research and development policy and practice. In Myanmar, numerous research attempts have been made to understand the empowerment of women and gender equality from different perspectives. However, little is known about the role of rural women in environmental management in Myanmar. 


\section{Research Objectives}

Hence, this research aims to appraise the role of women in environmental management in Myanmar.The three specific objectives are:

1. to analyze how environmental management systems are conducted by the successive Myanmar governments

2. to study the women's perspective on the environment

3. to investigate how local resources are managed by Myanmar women

This paper argues that women are directly affected by the state of the environment because of the traditional gendered roles imposed by the patriarchal social system on the women such as providing and preparing food; cleaning the house; washing the clothes and dishes; gathering fuel wood; fetching water; and taking care of the children.

\section{Materials and Methods Used}

A qualitative and quantitative research methodology with a case study research design has been chosen. The case described in this research is based on field data collected on research trips. Both statistical data and official statements are used to support the case analysis. This research makes use of two types of data. The first is the secondary source materials obtained from past studies on women's involvement in environmental protection and management. The second is primary data obtained through a questionnaire survey of women in selectedvillages. The respondents have been randomly selected from this study area. The study presentsfindings from three main topics: environmental management policies in Myanmar, literature reviews on women and environmental management and the nature of women's workfor environmental protection and conservation.

\section{Environmental Management Policies in Myanmar}

In Myanmar, the main institution involved in promoting environmental awareness in the country is the National Commission of EnvironmentalAffairs (NCEA) established in February 1990. The environmental consciousness is more or less ingrained in Myanmar people through Buddhist teachings. In Buddha's teaching, planting of trees, making gardens and parks, constructing bridges, digging wells, building rest houses and monasteries are described as acts of merit. Historical records show that environmental conservation works were initiated by the last dynasties of Myanmar kings who with far-sightedness proclaimed the valuable teak forests as royal property and levied royalties on teak properly extracted withroyal permission.

There was no central coordinating body for environmental matters before the creation of the National Commission for Environmental Affairs (NCEA) in 1990. This action followed the introduction of a market-oriented economic policy in 
1988, when the need for a central institution to safeguard environmental interests quickly became clear. The NCEA comes under the Ministry of Foreign Affairs and coordinates the work of various other ministries and departments. The nineteen members of the NCEA are the heads of department of various ministries. The objectives of the NCEA are to set environmental standards, create environmental policies for using natural resources, issue rules and regulations to control pollution, and to create short and long term environmental policies which balance environmental needs and development requirements.

The country's main environmental policies have embraced promoting harmony and balance between the protection of its environment and the goal of achieving economic growth. Based on these policy principles, various laws have been promulgated to govern the environment sector. Although Myanmar has a number of environmental laws and regulations, it lacks the institutional framework to carry out 'protection and conservation of the environment' so as to achieve sustainable development by implementing these laws, which were not crafted on the basis of sound science or debated democratically to reflect the legitimate livelihood concerns of the population. On top of that, there is no evidence of a political commitment to deal with environmental affairs effectively even under these less than perfect laws. In addition, while Myanmar is party to several international treaties such as the Convention on Biological Diversity (CBD), Myanmar has not incorporated the provisions contained in these agreements into domestic law. For example, national laws do not currently require environmental impact assessments (EIA) or public participation by local communities in the decision-making processes of large-scale development projects. There are no laws that comprehensively regulate pollution, no standards to adequately protect biodiversity, develop resettlement plans, or provide compensation.

The NCEA was also the focal point for the Myanmar National Environmental Performance Assessment (EPA), a report done in collaboration with several international organizations such as the Asian Development Bank (ADB), United Nations Environmental Programme (UNEP), Institute of Global Environmental Strategies, and the National Institute for Environmental Studies of Japan. On 5 December 1994, Myanmar adopted a National Environmental Policy to ensure the incorporation of environmental concerns in planning for economic development. This policy emphasizes "the responsibility of the State and every citizen to preserve its natural resources in the interest of present and future generations."

In the same year, the NCEA also drafted two laws: the Environmental Protection Law and the Environmental Impact Assessment Rules, but both have remained unapproved. Between 1997 and 2000, a set of environmental protection provisions was drafted and redrafted by the government, with technical inputs and support from the United Nations Environment Programme, but none has been approved as law. The establishment of the NCEA and the emergence of a national environmental policy in Myanmar were driven by global awareness and initiatives taken by the United Nations.

In 2005, the NCEA was transferred to the Ministry of Forestry (MoF), and the Minister of Forestry assumed the role of the NCEA chairperson. The NCEA was reorganized into the National Environmental Conservation Committee (NECC) in April 2011 based on Notification No.21/2011, (20/04/2011) of the 
Office of the President. The NECC is considered responsible for guiding national activities to tackle climate change-related problems. Furthermore, the NECC manages and coordinates all climate change related activities in Myanmar, including the development of climate change related policies and strategies and corresponding programmes of action. The NECC works in conjunction with the Environmental Conservation Department, established in 2012 as one of six subdepartments of the Ministry of Environmental Conservation and Forestry (MOECAF). The Environmental Conservation Law was passed in 2012 and Environmental Conservation Rules were issued 2013. In 2016, the Ministry of Natural Resources and Environmental Conservation was formed and the NECC was placed under this ministry.

\section{Environmental Provisions in the 2008 Constitution}

Under the new 2008 Constitution, the government "shall protect and conserve the natural environment" (Chapter 1, Section 45). The national legislature can, but does not need to, enact laws to protect the environment and help restore areas degraded or damaged by mining and forestry activities or those that have experienced destruction of plants, wildlife, and habitat (Chapter 4, Section 96). State and Division Legislatures also have the power to regulate environmental protection, but within the boundaries of legislation passed by the National Legislature (Chapter 4, Section 196). In addition, every citizen has the duty to "assist" the government in carrying out environmental conservation (Chapter 8, Section 390). With regard to environmental protection, the 2008 Constitution does not guarantee to the people the right to a clean and healthy environment although many other national constitutions provide such a right. The constitution does not have any clear language on sustainable development and recognition of the rights of civil society such as freedom of information, participation in natural resource management, customary land ownership, information in local languages, and equitable benefit sharing.

Many organizations are active in Myanmar on projects and programs related to environmental protection and sustainable development. This includes a broad range of community-based organizations, grassroots organizations, national and international NGOs, UN agencies, and church groups both based in governmentcontrolled areas of Myanmar ('inside') and those based in the Thai and Chinese border regions ('border groups'). Many organizations take the 'traditional' conservation approach or the rights-based approach or both. Organizations that are using a rights-based approach work from the perspective of sustainable development and livelihoods and subsequently focus on issues such as food security, land tenure and rights, and community development and organizing. Conservation organizations tend to focus specifically on environmental protection, although with varying strategies to achieve their common goal. Organizations working on environmental issues also focus on environmental awareness, education and training, policy development, advocacy and networking. 


\section{Literature Reviews on Women and Environmental Management}

Many studies women and environmental management have shown that women are significant actors in natural resource management and major contributors to environmental rehabilitation and conservation. In addressing some key environmental problems, women play a dominant role. Women, through their roles as farmers and as collectors of water and firewood, have a close connection with their local environment and often suffer most directly from environmental problems. Women direct contact with environment has produced their deep-knowledge about the environment. Thus, women have served as agriculturalists, water resources managers and traditional scientists among others. Women are not only knowledgeable about the environment, they are also protective and caring (Shettima, 1996).

Akwa (2008) states that the women's direct contact with the environment has enhanced their knowledge about conservation matters as they have served as agriculturists, water resources managers, and traditional scientists, among others roles Women are protective and caring as they know that their lives depend on a healthy environment.

Etta (1999) observed that women, being primarily responsible for domestic and household management, interact more intensively with both the natural environment and the built environment than men. They are more likely to suffer from a degraded home, neighbourhood, and city environment and to shoulder more of the burden that goes with living in poor housing and communities with inadequate residential and health infrastructure, since they spend more time at home and in its immediate vicinity.

Vandana Shiva (1998) argues that women are the original givers of life and caretakers of the environment, while it is the Western patriarchal development strategies and Western science that have displaced the feminine principle and victimized women, non-Western people and the environment. Patriarchal relations still govern the economic behavior of most ruralhouseholds with men controlling and managing most agricultural resources. Women's attemptsto increase their earning capacity by engaging in independent agricultural or offfarm activitiesare severely limited by lack of time and customary social constraints on their access to economicresources. Shiva further argued that the marriage of patriarchy and capitalism had subjugated women to the environment.

In the same manner, Bina Agarwal (1993) also identified the victimization of women in political, economic and gender terms. For her, patriarchy and the process of satisfaction and privatization impoverish women and render them the hardest hit by environmental damage. Similarly, the feminist theory asserted that patriarchy is the main cause of women's oppression, subordination and abuse.

Both Shiva and Agarwal asserted that women should be the central actors in environmental management. This is because of their closeness to the resource base due to their daily survival tasks and their being caught in the maelstrom of environmental degradation. They believed that being the privileged caretaker of the environment is the key to women's empowerment. Women are propelled to 
actions more conducive to environmental protection and regeneration as the reduction of the shifting cultivation, tree planting.

Dankelman and Davidson (1998) observed that women play a key role in managing their natural surroundings and adopt several mechanisms to deal with the kinds of environmental crises they face. They, however, observe that the responses of governments have not been significant and as a result women, men, and children continue to face problems including pollution, poor services, human waste pollution, fumes from household fuel, and the consequences of soil erosion and flooding.

Custers (1997) mentioned that traditionally men have been working in the field whereas women have been involved in pre-planting and post-harvesting activities at home. Some men move to take up the construction work in the city. The women's responsibilities are the house and the men are to earn for the family. Although women may go out to work for the development of society, she still hasthe major responsibility to look after the family welfare.

Maye (1994) pointed that women worldwide are part of a growing movement for the protection of the living world, environmental health and security, justice and the alleviation of poverty. Women play a major part in the protection of biological diversity through their many roles and responsibilities.

Much has been said about women's activities in environmental improvement and protection. Moser (1991) distinguishes three roles for women:

1. As managers or maintainers of the natural environment

2. Rehabilitators of the natural environment in the sense of sustainable development and

3. As innovators in the use of appropriate technology in the creation of new environments.

According to the World Bank (1991), Women play an essential role in the management of natural resources, including soil, water, forest and energy and often have a profound traditional and contemporary knowledge of the natural world around them. Based on these understandings, I want to examine a major hypothesis in this research paper: Are there any relationships between women and environmental management? My hypothesis is that the answer to the question is yes. The reason why I believe so is based on the following assumptions. Since childhood, women in rural areas are trained to care for their siblings and to collect water or firewood during school holidays. They are traditionally aware of how to use fuel wood properly, how to get and store safe drinking water, and which plants can be used as indigenous medicine. Thus rural women play a dominant role in environmental protection and conservation in their community. 


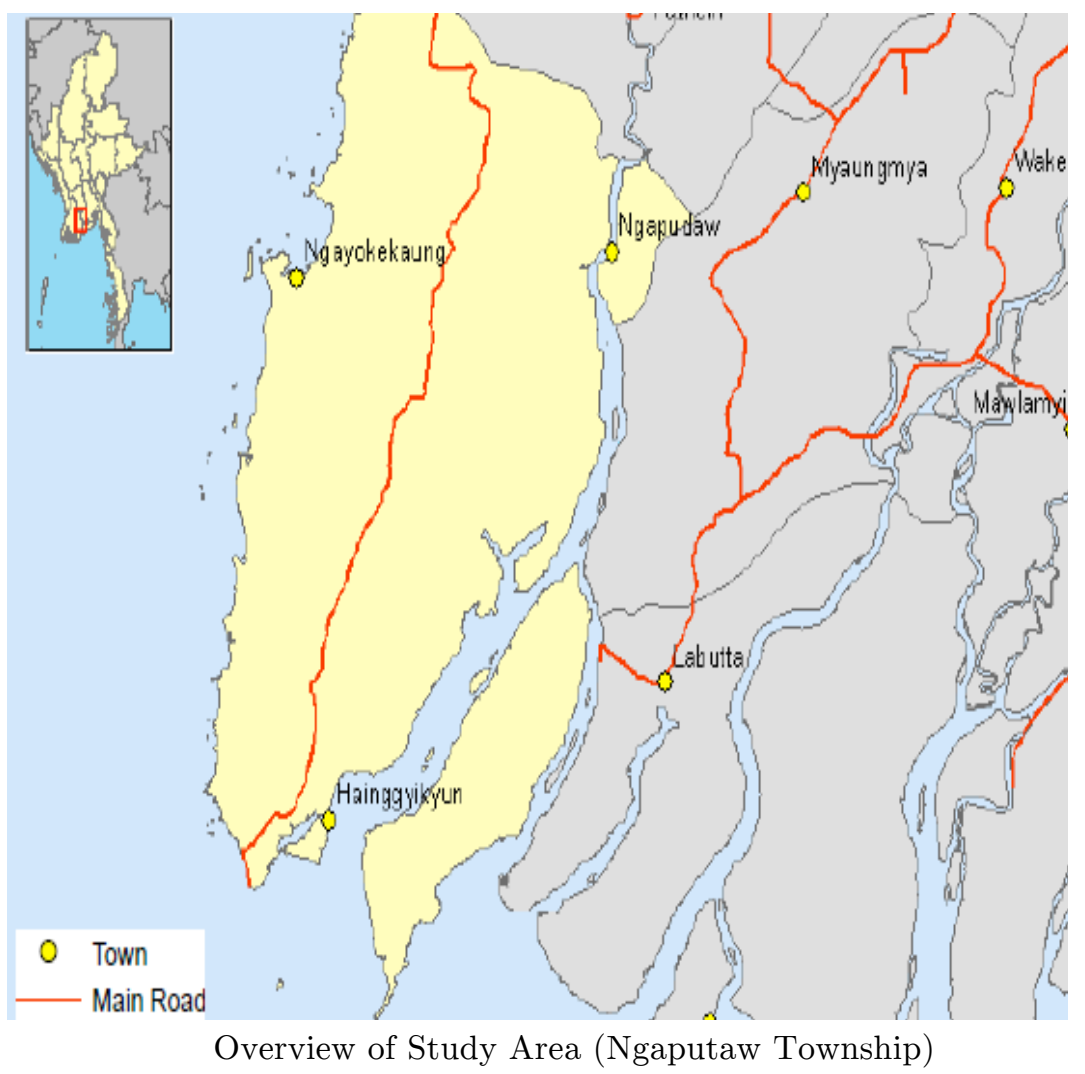

Ngaputaw Township is selected as the study area. Data for the study have been collected from Ngaputaw General Administration Department and Village Administrators from the selected villages using semi-structured and unstructured interviews. Ngaputaw Township occupies the extreme southwestern portion of Pathein District, in Ayeyarwady Region. It is located between the Bay of Bengal on the West and the Nga Wun River on the East. It is 21 miles from Pathein. The total area is 1404.19 square miles and there are 4 urban wards and 83 village tracts which contain 414 villages. Ngaputawhas 168,776 inhabitants with 84,182 males and 84,549 females, living in the Township in 2014. Some $90 \%$ of the populations livein rural areas. The main sources of livelihoods are fisheries, agriculture and income from the salt industry. Approximately 40 percent of families are engaged in agriculture, 40 percent are engaged in the salt and fishing industry and 20 percent are sellers. The respondents have been randomly selected from the villages in the study area. A total of 64 respondents participated in the study which is not so high number compared with population that living in the town.

\section{Women in Local Resource Management}

The environmental management is the participation of all those who make use of environment resources. Environmental management has been related to Sustainable development. Both concepts, 'environmental management' and 'sustainable development', have not only been widely debated, but also institutionalized. The environmental management is part of an integrated 
activity practised in people's day to day life. They perceive the environment in a broader manner: it is not only confined to the geographical setting that they occupy and the resources with which they interact throughout their lives, but also includes external systems that they maintain relationships with. Environmental management includes the management of local resources.

The age and marital status of the women in the study area is shown in Table 1. Only $12.5 \%$ of the women surveyed are below the age of 20 years. Some $79.7 \%$ of the women are between 20 and 59 years, while only $7.8 \%$ are above 60 years. The implication of this age distribution is that most of the women are still in their prime and hence energetic enough to take active part in environmental management activities.

Table 1: Age and marital status of the women in the study area

\begin{tabular}{|c|c|c|}
\hline Age Group & Number & Percentage \\
\hline Under 20 years & 8 & 12.5 \\
\hline 20-39 years & 39 & 60.9 \\
\hline 40-59 years & 12 & 18.8 \\
\hline 60 and above & 5 & 7.8 \\
\hline Total & 64 & 100.0 \\
\hline Marital Status & Number & Percentage \\
\hline Married & 52 & 81.3 \\
\hline Single & 12 & 18.8 \\
\hline Total & 64 & 100.0 \\
\hline
\end{tabular}

Source: Field Survey, 2016

Marital Status indicates that $81.3 \%$ of the women are married while only 18.8 $\%$ are single. Both married and single women are involved in environmental protection. This high proportion of married women in the study area suggests that they are likely to be more responsible in protecting and keeping the environment clean because of their roles as home keepers.

Women provide water for their various domestic activities. They can be called water mothers. , Their marital status doesn't affect their status to become water mothers. Myanmar Women are 58\% of the total population of Myanmar and are considered key stakeholders in the objective to ensure sustainable development and management of water resources at all levels. Where women do not have access to tap water, they make use of rainwater, wells, and rivers. At the household level, the burden of fetching water for cooking, washing falls on the women and girls. It is often women who decide where to collect water, how to draw, transport, and store it, what sources should be used for which purposes, and how to purify drinking water. Women are almost the exclusive suppliers of water for household use.

A good example of women in water resource management was found in Ngaputaw Township. Although it is set between numerous creeks and rivers, there is no fresh water for drinking. Villagers in the township of Ngaputaw traditionally source drinking water from rainwater, communal water ponds and wells as most villages have no access to piped water. The task of fetching water usually falls to the women and children. To get water for their various domestic 
activities, they walk for one mile with their empty buckets. They carry two plastic containers per trip with a capacity of 10 gallons each. More than one trip per day may be needed to cover all the household needs and this limits the amount of time that women can spend on other activities, whether income earning, educational or leisure.

During the dry season, the probability of these water sources drying up increases, forcing them to walk even further for alternative water sources, which are almost always contaminated. In March and April 2016, Myanmar is the facing El Nino effect of severe heat, drought and water scarcity. The 148 villages in Ngaputaw Township faced drinking water shortages since mid-January as their hand-dug wells dried up. "The lakes in our village have run dry since it is extremely hot. We have to bring in water from the lakes in the forest which is as much as two hours away. As all of the residents in nearby villages, go to fetch water there, we have to wait until about 12 p.m so as to get a pot of water," said a woman in Kothein village. When there is a water shortage, women more than men are responsiblefor managing the water. For example, fresh water is used first to wash the rice for cooking, then rice-washed water is re-used for dish cleaning, and then dish-cleaned water is re-used for tree planting.

Women have the primary responsibility for meeting household energy needs through fuel collection, preparation (chopping and drying), and use (cooking and tending the fire). Children, especially girls, take part in many of these tasks. All these tasks may take many hours per day. The World Bank estimates that threequarters of Myanmar's energy needs are met by fuel-wood and charcoal to meet such needs as cooking, lighting, and heating. In Myanmar, rural households still use firewood for cooking. In Asia, more than 75\% households in Cambodia, Lao People's Democratic Republic and Nepal depend on firewood.

In Myanmar, the main causes of deforestation are small-scale agriculture, shifting agriculture, commercial logging, and fuel wood production, while the underlying cause is widespread poverty. For a developing country like Myanmar, biomass, mainly in the form of fuel wood, is the largest source of energy. The oil import shortages due to foreign exchange constraint in the 1980s led to a drastic increase in fuel wood consumption. Kerosene is too costly for most rural and poor urban households whilst alternative fuels like gas and electricity are still unavailable in most of rural Myanmar. As a consequence, the use of biomass energy has increased greatly, reaching to 73 per cent of primary energy supply in the 2013 (ADB 2013), while placing a huge burden on forests. A small number of people use agriculture residues such as cotton and pigeon pea stalk, sugar cane, paddy straw, rice husks, sesame stalks and palm leaves. The government's effort to introduce the use of wastes from agricultural crops in place of fuel wood was largely ineffective. When domestic fuel becomes more commercialized and collection is oriented towards large-scale organized sale and charcoal making, men's participation increases. But so long as technology and marketing are absent, the task of fuel gathering is relegated to women.

In the study area, the survey revealed that almost $95.3 \%$ of the women used firewood for cooking while only $1.6 \%$ used wastes from agricultural crops (Table2 ). Women can carry loads up to 35 kilogram over a distance as much as 3 miles from home. The weight largely exceeds the maximum weights of 20 kilograms permissible by law in many countries. 
Table 2: Fuel for cooking

\begin{tabular}{|c|c|c|}
\hline Energy Usage & Number & Percentage \\
\hline Firewood & 61 & 95.3 \\
\hline Waste from agricultural crops & 1 & 1.6 \\
\hline Charcoal & 2 & 3.1 \\
\hline Total & 64 & 100.0 \\
\hline
\end{tabular}

Source: Field Survey, 2016

According to the results of the questionnaire survey of women's participation in environmental management, it can be found that women are main actors in environmental sanitation at homes and communities. About $78.1 \%$ of the women survey indicated that they clear their surroundings daily, $10.9 \%$ do it weekly while $10.9 \%$ do it occasionally. When asked the major activity they perform in cleaning the environment, majority $60.9 \%$ indicated sweeping. This is followed by weeding $23.4 \%$ and clearing of drainage $14.1 \%$ other activities such as packing refuse, filling ditches constitutes $1.6 \%$. (Table-3)

Table 3: Women's participation in environmental management

\begin{tabular}{|c|c|c|}
\hline $\begin{array}{l}\text { Environmental sanitation at homes and } \\
\text { communities }\end{array}$ & Number & Percentage \\
\hline Daily & 50 & 78.1 \\
\hline Weekly & 7 & 10.9 \\
\hline Occasionally & 7 & 10.9 \\
\hline Total & 64 & 100.0 \\
\hline Major activities in environmental cleaning & Number & Percentage \\
\hline Sweeping & 39 & 60.9 \\
\hline Weeding & 15 & 23.4 \\
\hline Cleaning drainage & 9 & 14.1 \\
\hline Others & 1 & 1.6 \\
\hline Total & 64 & 100.0 \\
\hline
\end{tabular}

Source: Field Survey, 2016

Women play a major role in food production. Some $82.8 \%$ of the women surveyed were engaged in farming, $6.3 \%$ in the salt industry and fishing industry respectively. (Table 4) This confirms findings from other studies that women participate greatly in food production especially in developing countries (Etta, 1999). One of the ways of protecting the environment and reducing hazards such as windstorms and erosion is by planting trees. 
Table 4: Food production

\begin{tabular}{|lr|r|r|}
\hline \multicolumn{2}{|c|}{ Involvement in food production } & \multicolumn{1}{c|}{ Number } & \multicolumn{1}{c|}{ Percentage } \\
\hline Farming & 53 & 82.8 \\
\hline Salt Industry & 7 & 6.3 \\
\hline Fishing & Total & 64 & 100.0 \\
\hline \multicolumn{2}{|r|}{ Tree Planting } & Number & Percentage \\
\hline Fruit Trees & 54 & 84.4 \\
\hline Flowers & 10 & 15.6 \\
\hline & Total & 64 & 100.0 \\
\hline
\end{tabular}

Source: Field Survey, 2016

Women participated in providing seeding in nursery and flowers to beautify the environment. According to Ester Boserup (1989) and others, women haveplayed majorroles from gathering seeds to the production of food, through slash-and-burn cultivation. Because food collection required a thorough knowledge of plant and animal growth, maturation and fruition or reproduction, women have been credited with the discovery of domestication and cultivation of plants and animals and invented selective breeding. This again supports previous findings that women are actively involved in tree planting. When asked what trees or flowers were planted, $84.4 \%$ of those interviewed in Ngaputawindicated fruit trees, $15.6 \%$ flowers. Fruit trees (e.g Gourd, Mangoes etc.) constitute the bulk of the trees planted by most of the women. This is done with the twofold objectives of protecting the environment and providing fruits for the household. In the study area, the environmental resources used by women have been managed using their indigenous knowledge.

\section{Conclusion and Recommendation}

Based on the results discussed in the previous sections, the following conclusions can be made. Both married and single women are involved in environmental protection. However, the bulk of the women involved in environmental protection are married women (81.3\% of them). This high proportion of married women in the study area suggest that they are likely to be more responsible in protecting and keeping the environment clean because of their roles as home keepers. Women being primarily responsible for domestic and household management interact more intensively with both the natural and built environment more than men.

Women play multiple roles in the family, community, and in the protection and management of the natural resources. Their multifaceted roles lead to their multiple burdens. Women's perspective on the connections of women and environment are linked to the domestic roles of women. Further, women's roles are directly affected by the state of the environment because women more than men are the main users of resources like coastal and water resources, forest resources and other land resources. 
Thus this paper has discussed the various ways women have participated actively in environmental protection and conservation. The empowerment of women through sustainable development and in relation to the protection of the environment must be recognized. Environmental knowledge and education should be expanded in rural area through the radios and mobile phones. Women should be allowed to participate at the local, regional, national and international levels on environmental issues. As resource managers, women should be consulted and supported in what they are already doing to protect the environment specifically, more women should be involved in decision making with regards to policies, programmes or funding of environmental projects.

\section{References:}

Akwa. L (2008) Analysis of Fuel Wood Utilization Among Rural Women in Akwanga Area of Nasarawa State, Nigeria. The Abuja Journal of Geography and Development, Vol.I

Agarwal, Bina (1993) The Gender and the Environment Debate: Lessons from India. Feminist Studies Vol. 18 No. 1

Boserup. E. 1989,Women's Role in Economic Development, London, Earthscan http://burmalibrary.org/docs/women's_role

Dankelman. I and Davidson, J (1997) women and environment in the third world, Landon; Earthscan publication.

Etta, F.E (1999) Maroko low- income settlement in Lagos, Nigeria; Gender and Urban Natral resources management in D. L. smith women managing resources Mazigira institute, Nairobi.

Gutter, Peter, 2001, Environmental Law in Burma, Legal Issues on Burma

Journal, Burma Lawyers Council, No 9, August 2001, http://burmalibrary.org/docs/LIOB09environment_and_law_in_burma.htm.

Horton, Susan. 1996. Women and industrialization in Asia: Overview. In Women and industrialization in Asia, ed. S. Horton: 1-42. New York and London: Routledge.

Khin-Maung, M. I. 1997 The Myanmar labour force: Growth and change, 1973-83. Singapore: ISEAS

Khin Ni Ni Thein, Prof. Dr. 2014, Myanmar Case Study intervention on behalf of Women

for Water Partnership (WfWP) ,"Women's empowerment and leadership for sustainable water governance and development: Myanmar Case" www. 2014_Statement_ Prof_Dr._Khin_ NiNi_ Thein.com

Matsui, Yayori. 1989 Women's Asia. London and New Jersey: Zed Books.

Maung Maung Tin, U Konbaungzet Mahayazawintawgyi, Vol. III, Yangon, Yabye Publishing House, 2004

Maye.A, 1999 Women: the Resource manager UNEP, Vol-6, No-4.

Myint Han, "1997, Fuel wood substitution in Myanmar." In Savage, V.R. and Kong, L.L.L., eds.,Environmental Stakes: Myanmar and Agenda 21. Singapore: NUS, 1997

Myint Myint Khin, 1997 Women in development: The situation of women in Myanmar.

Nzomo, M. (1992). "Policy Impacts on Women and Environment" in Khasiani, S.A.(ed.). Groundwork: African Women as Environmental Managers. Nairobi, Kenya: African Center for Technology Studies,

Shiva, Vandana. 1998 Staying Alive: Women, Ecology and Survival in India. London Zed Books

Shettima, A. G (1996). Gender issues in monitoring the environment: The case of Rural Nigeria. A paper presented at the 39th Annual conference of the Nigerian geographical Association, 5th -8th May, at university of Maiduguri.

Tan, Alan K.J., 2003Preliminary Assessment of Myanmar's Environmental law, Faculty of Law, National University of Singapore, Asia-Pacific Centre for Environmental Law (APCEL)

Tun Myint, 2007 Environmental Governance in the SPDC's Myanmar' in Myanmar: The state, community and the environment, Trevor Wilson and Monique Skidmore (eds), Australian National University, ANU E Press and Asia Pacific Press, 2007

Tun Myint, 2016A Perspective on Burma, www.ref-msea.org/burma.pdf, last Accessed 12 February 2016.

UNICEF. 1995 Children and women in Myanmar: A situation analysis. Yangon: UNICEF. 
World Bank, 1991 Women and Development in Malawi: Constraints and Actions, Washington, DC, World Bank.

-2014 Myanmar Population and Housing Census, Vol-2, Department of Population, Ministry of Immigration, May 2015

-2008 Constitution of Myanmar

-Environmental Conservation Law, 2012

-Facts and Figures of General Administration Department, Ngaputaw, General Administration Department, 2013

-National Environmental Policy, 1994 